\title{
ISLAMIC SOCIAL REPORTING PADA PERBANKAN SYARIAH DI INDONESIA
}

\author{
Kholid Murtadlo, Nuraeni \\ kholidmurtadlo@yudharta.ac.id,nuraeni@yudharta.ac.id \\ Universitas Yudharta Pasuruan
}

\begin{abstract}
This study aims to determine how the disclosure of Islamic Social Reporting (ISR) in Islamic banking and the factors that influence it. The disclosure of social responsibility by Islamic banking should refer to disclosure standards based on Islamic principles. The standard used in this study is the Islamic Social Reporting index, which is a reporting framework based on Islamic principles proposed by Haniffa and developed by Haniffa and Hudaib and Othman et al. The results of the study show that the Firm Size and Leverage variables have a significant effect on ISR while Profitability and the composition of the board of commissioners have no significant effect on ISR.
\end{abstract}

Keywords: Islamic Social Reporting, Islamic Banking.

\section{PENDAHULUAN}

Perkembangan CSR di Indonesia telah mengalami peningkatan baik dari sisi kualitas maupun kuantitas dibandingkan tahun-tahun sebelumnya. Hal ini dapat terlihat dari meningkatnya item pengungkapan tanggung jawab sosial dalam laporan keuangan perusahaan. Dalam Islam Corporate Social Responsibility (CSR) erat kaitannya dengan perusahaan yang menjalankan bisnis sesuai dengan konsep syariah yang diharapkan perusahaan tersebut dapat melakukan tanggungjawab social perusahaan secara Islami.

Ekonomi Islam sendiri telah membahas tentang Corporate Social Responsibility (CSR) sebelum dikeluarkannya Undang-undang Nomor 21 Tahun 2008 Tentang Perbankan Syariah, hal tersebut dapat dilihat dalam laporan sumber dan penggunaan dana zakat dan kebajikan. Dalam Al-Quran surah at-Taubah ayat 60 dijelaskan:

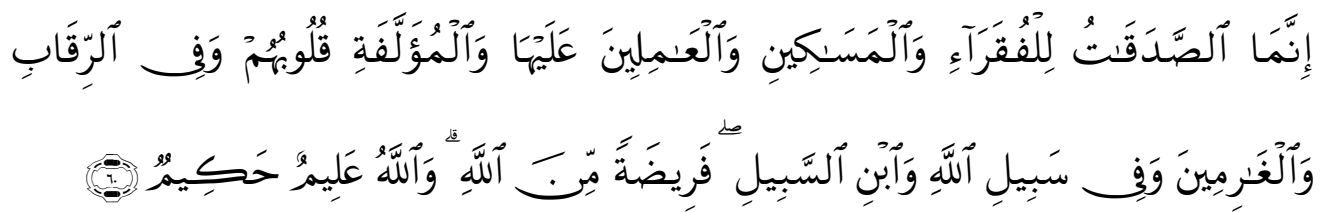

Sesungguhnya zakat-zakat itu, hanyalah untuk orang-orang fakir, 
$318\}$ Y Pengungkapan islamic Social Reporting pada Perbankan Syariah

orang-orang miskin, pengurus-pengurus zakat, Para mu'allaf yang dibujuk hatinya, untuk (memerdekakan) budak, orang-orang yang berhutang, untuk jalan Allah dan untuk mereka yuang sedang dalam perjalanan, sebagai suatu ketetapan yang diwajibkan Allah, dan Allah Maha mengetahui lagi Maha Bijaksana.

Aktivitas CSR pada perbankan syariah diselenggarakan sesuai dengan undang-undang No 21 Tahun 2008, dimana bank syariah dapat melakukan kegiatan bisnis, sosial yang bisa disalurkan kembali kepada orang yang berhak menerimanya. Dasuki \& Dar mengatakan bahwa, pada perbankan syariah tanggung jawab sosial relevan untuk dibicarakan mengingat beberapa faktor diantaranya adalah perbankan syariah berlandaskan prinsip syariah yang meminta mereka untuk beroperasi dengan landasan moral, etika dan tanggung jawab serta penghindaran dari kerusakan dan kemiskinan. Untuk itu nilai norma yang digunakan dalam pengungkapan tanggung jawab sosial pada perbankan syariah adalah nilai-nilai agama Islam yang disebut juga nilai-nilai syariah. ${ }^{1}$ Sehingga dalam hal ini pengungkapan CSR dalam perbankan syariah seringkali dikenal dengan istilah Islamic Social Reporting dengan tujuan untuk akuntabilitas dan transparansi. ${ }^{2}$ Islamic Social Reporting (ISR) pertama kali dikemukakan oleh Haniffa lalu dikembangkan oleh Othman et al. di Malaysia. ${ }^{3}$ Haniffa mengungkapkan bahwa adanya keterbatasan dalam pelaporan sosial konvensional sehingga ia mengemukakan kerangka konseptual Islamic Social Reporting berdasarkan ketentuan syariah yang tidak hanya membantu pengambilan keputusan bagi pihak nasabah muslim melainkan juga untuk membantu perusahaan dalam melakukan pemenuhan kewajibannya terhadap Allah Subhanaahu wa Ta"ala dan masyarakat.

Dalam hal social reporting, kondisi perusahaan sedikit banyak juga mempengaruhi kinerja serta luas penyajian laporan tahunan termasuk laporan tanggung jawab sosial perusahaan. Kondisi sebuah perusahaan dapat

1 Dusuki, A.W.,\& Dar, H. (2005). Stakeholders' perceptions of Corporate Social Responsibility of Islamic Banks: Evidence From Malaysian Economy. International Conference on Islamic Economics and Finance.

${ }^{2}$ Haniffa, R. (2002). Social Reporting Disclosure-An Islamic Perspective. Indonesian Management \& Accounting Research 1 (2), pp.128-146.

${ }^{3}$ Othman, R., Md. Thani, A., K. Ghani, E. (2009). Determinants of Islamic Social Reporting Among Top Shariah-Approved Companies in Bursa Malaysia. Research Journal of International Studies-Issue 12 (October, 2009).

..::: Malia: Jurnal Ekonomi Islam, Volume 10 Nomor 2 Juni 2019 :::... 
diketahui dari tipe perusahaan, ukuran perusahaan, dan profitabilitas perusahaan. ${ }^{4}$ Pada perusahaan yang memiliki tipe perusahaan yang lebih tinggi (high-profile) cenderung mengungkapkan kegiatan sosial perusahaan lebih luas dibandingkan tipe perusahaan yang lebih rendah (lowprofile). Sedangkan untuk ukuran perusahaan, perusahaan yang besar memiliki aktivitas yang lebih banyak dan kompleks serta mempunyai dampak yang lebih besar terhadap masyarakat, memiliki shareholder yang lebih banyak, serta mendapat perhatian lebih dari kalangan publik, oleh karena itu perusahaan besar cenderung mendapat tekanan yang lebih untuk mengungkapkan pertanggungjawaban sosialnya.

Lestari menemukan bahwa profitabilitas berpengaruh terhadap ISR sedangkan ukuran perusahaan, umur perusahaan, proporsi dewan komisaris independen tidak mempengaruhi pengungkapan ISR. ${ }^{5}$ Sedangkan othman et al. menemukan bahwa ukuran perusahaan, profitabilitas, dan ukuran dewan direksi muslim berpengaruh secara signifikan terhadap tingkat pengungkapan ISR, sedangkan tipe industri bukanlah faktor penting yang mempengaruhi ISR. Faktor lain yang mempengaruhi ISR adalah kemampuan perusahaan dalam mengelola tingkat Leverage-nya. ${ }^{6}$ Leverage adalah Semakin tinggi tingkat Leverage, maka akan mengurangi pengungkapan tanggung jawab sosial yang dibuatnya. ${ }^{7}$ Berdasarkan uraian diatas peneliti tertarik untuk mengetahui bagaimana Islamic Social Reporting Pada Perbankan Syariah di Indonesia.

\section{KAJIAN TEORI}

\section{Corporate Social Responsibility (CSR)}

CSR merupakan suatu komitmen perusahaan selaku pelaku bisnis untuk bertindak secara etis dan berkonstribusi terhadap peningkatan ekonomi berkelanjutan, bersamaan dengan peningkatan

\footnotetext{
4 Yuniarti, Emylia (2003) "Pengungkapan Informasi Pertanggung jawaban Sosial Pada Perusahaan yang Terdaftar di BEJ". Jurnal Telaah dan Riset Akuntansi. Vol 1, No.2: 240252.

${ }^{5}$ Hendriksen, Eldon S dan Widjajant, Nugroh “Teori Akuntansi”. Edisi ke-4 jilid 2. Jakarta: Erlangga.

${ }^{6}$ Rizkiningsih, Priyesta. 2012. "Faktor-Factor yang Mempengaruhi Pengungkapan Islamic Social Reporting (ISR) : Studi Empiris pada Bank Syariah di Indonesia, Malaysia dan Negara -Negara Gulf Cooperation Coincil". Skripsi. Universitas Indonesia.

7 Utomo, Muhammada Muslim (2000) "Prektek Pengungkapan Sosial pada Laporan Tahunan Perusahaan di Indonesia (Studi Perbandingan antara Perusahaan-perusahaan High Profile dan Low Profile)". Makalah disajikan pada SNA III.
}

..::: Malia: Jurnal Ekonomi Islam, Volume 10 Nomor 2 Juni 2019 :::.. 
320 \} Pengungkapan islamic Social Reporting pada Perbankan Syariah

kualitas hidup dari karyawan dan keluarga serta masyarakat secara lebih luas.

Terdapat beberapa teori yang melandasi adanya pengungkapan tanggung jawab sosial perusahaan. Teori yang dimaksud yaitu:

a. Teori Keagenan (Agency Theory)

Menurut Jensen and Meckling dalam penelitian Febrina dan Suaryana, teori keagenan mengungkapkan adanya hubungan antara principal (pemilik perusahaan atau pihak yang memberikan mandat) dan agent (manajer perusahaan atau pihak yang menerima mandat) yang dilandasi dari adanya pemisahan kepemilikan dan pengendalian perusahaan, pemisahan penanggung risiko, pembuatan keputusan dan pengendalian fungsi-fungsi. Teori keagenan menyatakan bahwa perusahaan yang menghadapi biaya kontrak dan biaya pengawasan yang rendah cenderung akan melaporkan laba lebih rendah atau dengan kata lain akan mengeluarkan biaya-biaya untuk kepentingan manajemen, salah satunya biaya yang dapat meningkatkan reputasi perusahaan di mata masyarakat yaitu biaya-biaya yang terkait dengan tanggung jawab sosial perusahaan. ${ }^{8}$

b. Teori Legitimasi

Teori legitimasi mengungkapkan bahwa perusahaan secara kontinyu berusaha untuk bertindak sesuai dengan batas-batas dan normanorma dalam masyarakat. Atas sahamnya tersebut pengusaha berusaha agar aktivitasnya diterima menurut persepsi pihak eksternal. $^{9}$

c. Teori Stakeholder

Stakeholder yaitu semua pihak yang memiliki hubungan dengan perusahaan baik yang bersifat mempengaruhi maupun dipengaruhi, atau bersifat langsung maupun tidak langsung. ${ }^{10}$ Teori stakeholder mengatakan bahwa perusahaan bukanlah entitas yang hanya beroperasi untuk kepentingannya sendiri tetapi juga harus memberikan manfaat bagi stakeholdernya seperti pemegang saham,

\footnotetext{
8 Hafiez Sofyaniet. al., "Islamic Social Reporting Index Sebagai Model PengukuranKinerjaSosialPerbankanSyariah (StudiKomparasi Indonesia dan Malaysia)", JurnalDinamikaAkuntansi, Vol. 4 No. 1,2012, h. 46.

9 Eddy Rismanda Sembiring. (2003). Karakteristik Perusahaan dan Pengungkapan Tanggung Jawab Sosial. Tesis. Universitas Diponegoro

${ }^{10}$ Hendriksen, Eldon S dan Widjajant, Nugroh "Teori Akuntansi". Edisi ke-4 jilid 2. Jakarta: Erlangga.
}

..::: Malia: Jurnal Ekonomi Islam, Volume 10 Nomor 2 Juni 2019 :::.. 
kreditor, konsumen, supplier, pemerintah, masyarakat, analis dan pihak lai).

d. Teori Kontrak Sosial

Perusahaan yang merupakan sekelompok orang yang memiliki kesamaan tujuan dan berusaha mencapai tujuan secara bersama-sama merupakan bagian dari masyarakat. Keberadaan suatu perusahaan sangat ditentukan oleh masyarakat dimana antara keduanya saling mempengaruhi. Oleh karena itu, agar terjadi keseimbangan, diperlukan kontrak sosial baik secara eksplisit maupun implisit sehingga terjadi kesepakatan yang saling melindungi kepentingan nya. $^{11}$

Tujuan dari pengungkapan tanggung jawab sosial perusahaan (Corporate Social Responsibility Disclosure) adalah agar perusahaan dapat menyampaikan tanggung jawab sosial yang telah dilaksanakan perusahaan dalam periode tertentu. Penerapan CSR dapat diungkapkan perusahaan dalam media laporan tahunan (annual report) perusahaan yang berisi laporan tanggung jawab sosial perusahaan selama kurun waktu satu tahun berjalan.

\section{Corporate Social Responsibility (CSR) dalam Prespektif Islam}

CSR dalam perspektif Islam menurut AAOIFI yaitu segala kegiatan yang dilakukan institusi finansial Islam untuk memenuhi kepentingan religius, ekonomi, hukum, etika dan discretionary responsibility sebagai lembaga finansial intermediari baik itu bagi individu maupun bagi institusi. Tanggung Jawab religius mengacu pada kewajiban menyeluruh bagi institusi finansial Islam untuk mematuhi hukum Islam pada seluruh kegiatannya. Sedangkan tanggung jawab ekonomi mengacu kepada kewajiban bank syariah mematuhi kelayakan ekonomi secara efisien dan menguntungkan. Kewajiban hukum mengacu pada institusi finansial Islam untuk mematuhi hukum dan peraturan di negara tempat beroperasinya institusi tersebut. Tanggung jawab etika yang dimaksud dalam AAOIFI yaitu menghormati masyarakat, norma agama dan kebiasaan yang tidak diatur dalam hukum. Sedangkan discretionary responsibility mengacu kepada ekspektasi yang diharapkan

\footnotetext{
${ }^{11}$ Hasibuan, Chrysanti dan Sedyono (2002) "Etika bisnis, Corporate Social Responsibility (CSR) dan PPM'. PPM Institute of Managemant, 27 November.
}

..::: Malia: Jurnal Ekonomi Islam, Volume 10 Nomor 2 Juni 2019 :::.. 
322 \} Pengungkapan islamic Social Reporting pada Perbankan Syariah

oleh pemegang saham bahwa institusi finansial Islam akan melaksanakan peran sosialnya dalam mengimplementasikan cita-cita Islam.

\section{Islamic Social Reporting (ISR)}

Banyak pendapat yang menjelaskan mengenai social reporting, Hannifa menyatakan bahwa social reporting adalah perluasan dari sistem pelaporan keuangan yang merefleksikan perkiraan yang baru dan yang lebih luas dari masyarakat sehubungan dengan peran komunitas bisnis dalam perekonomian. Beberapa hal penting dalam social reporting menurut perspektif Islam, yaitu pemahaman mengenai akuntabilitas, keadilan sosial dan kepemilikan sosial. Hal senada diungkapkan oleh Hannifa, Islamic Social Reporting (ISR) menggunakan prinsip syariah sebagai landasan dasarnya. Prinsip syariah dalam ISR menghasilkan aspek-aspek material, moral, dan spiritual yang menjadi fokus utama dari pelaporan sosial perusahaan. Islamic Social Reporting (ISR) merupakan perluasan dari pelaporan sosial yang tidakhanya berupa keinginan besar dari seluruh masyarakat terhadap peranan perusahaan dalam ekonomi melainkan berkaitan dengan perspektif spiritual. Untuk itu ISR lebih menekanan terhadap keadilan sosial dalam pelaporannya selain pelaporan terhadap lingkungan, kepentingan minoritas dan karyawan. ${ }^{12}$

\section{Ukuran Perusahaan (Size)}

Ukuran perusahaan menunjukkan besar kecilnya perusahaan. Semakin besar ukuran suatu perusahaan maka semakin mendapat perhatian daripasar maupun publik (Handayati, 2011). Berkaitan dengan teori keagenan dimana perusahaan besar akan mempunyai biaya keagenan yang lebih besar dibandingkan dengan perusahaan kecil, sehingga perusahaan besar akan mengungkapkan informasi secara lebih luas untuk mengurangi biaya keagenan $\mathrm{Hal}$ itu dikarenakan perusahaan yang lebih besar adalah perusahaan yang memiliki sumber daya lebih banyak daripada perusahaan yang lebih kecil dan perusahaan yang lebih besar memiliki pembiayaan, fasilitas, dan sumber daya manusia yang lebih banyak untuk dapat melakukan pengungkapan yang lebih sesuai dengan prinsip Islam.

${ }^{12}$ Nizar, M. Pengaruh Ekuivalen Nisbah Bagi Hasil Tabungan, Deposito, Dan Frekuensi Pencairan Pembiayaan Murabahah Terhadap Jumlah Nasabah Baru di BMT al-Yasini Wonorejo Pasuruan. 


\section{Profitabilitas}

Hubungan kinerja keuangan dengan tanggung jawab sosial perusahaan menurut Belkaoui dan Karpik dalam Angling paling baik diproxikan dengan profitabilitas, hal itu disebabkan pandangan bahwa tanggapan sosial yang diminta dari manajemen sama dengan kemampuan yang diminta untuk membuat suatu perusahaan memperoleh laba. Dari perspektif Islam, perusahaan harus bersedia untuk memberikan pengungkapan penuh tanpa melihat apakah perusahaan memberikan keuntungan atau tidak. Namun, Janggu berpendapat bahwa perusahaan dengan profiatabilitas yang lebih tinggi kemungkinan akan mengungkapkan informasi yang lebih dibandingkan perusahaan dengan profitabilitas yang kurang. ${ }^{13}$

\section{Proporsi Dewan Komisaris Independen}

Dewan komisaris merupakan puncak dari sistem pengelolaan internal perusahaan yang memiliki peranan terhadap aktivitas pengawasan dan adanya peraturan tentang keberadaan dewan komisaris independen akan semakin menambah efektifitas pengawasan yang dilakukan oleh dewan komisaris Menurut Leftwitch et.al dalam Hapsoro menyatakan bahwa komisaris independen dipersepsikan sebagai salah satu alat monitoring yang efektif terhadap perilaku manajemen. Dengan demikian akan berpengaruh pada pengendalian dan pengawasan terhadap pihak manajemen dalam operasi peusahaan, salah satunya adalah pengungkapan tanggung jawab sosial. Sehingga pada akhirnya tujuan perusahaan untuk memperoleh legitimasi dari stakeholder melalui pengungkapan tanggung jawab sosial dapat diperoleh. ${ }^{14}$

\section{Leverage}

Leverage yaitu rasio yang digunakan untuk menilai kemampuan perusahaan dalam memenuhi kewajiban jangka panjang. Tingkat pengelolaan hutang (Leverage) berkaitan dengan bagaimana perusahaan didanai dan apakah perusahaan didanai lebih banyak menggunakan hutang. Semakin tinggi tingkat Leverage maka semakin besar pula

\footnotetext{
${ }^{13}$ Sigit, Soehardi 1 (1999) "Pengantar Metodologi Penelitian Sosial-Bisnis-Manajemen. FE Universitas Sarjanawijaya Tamansiswa.

${ }^{14}$ Rizkiningsih, Priyesta. 2012. "Faktor-Factor yang Mempengaruhi Pengungkapan Islamic Social Reporting (ISR) : Studi Empiris pada Bank Syariah di Indonesia, Malaysia dan Negara-Negara Gulf Cooperation Coincil". Skripsi. Universitas Indonesia.
}

..::: Malia: Jurnal Ekonomi Islam, Volume 10 Nomor 2 Juni 2019 :::... 
$324\}$ Pengungkapan islamic Social Reporting pada Perbankan Syariah

kemungkinan perusahaan untuk melaporkan laba yang lebih tinggi. Demi memperoleh laba yang tinggi maka manajer akan mengurangi biayabiaya termasuk biaya untuk pengungkapan sosial. Keputusan untuk mengungkapkan informasi sosial akan mengikuti suatu pengeluaran untuk pengungkapan yang menurunkan pendapatan dalam penelitian Sembiring. Sesuai dengan teori keagenan maka manajemen perusahaan dengan tingkat Leverage yang tinggi akan mengurangi pengungkapan tanggung jawab sosial yang dibuatnya.

\section{METODE PENELITIAN}

\section{Populasi dan Sampel}

Populasi dalam penelitian ini adalah Perbankan Syariah di seluruh Indonesia. Adapun metode pengumpulan data yang digunakan adalah purposive sampling, yaitu data hanya data yang sesuai kriteria yang bisa dijadikan sampel. Kriteria-kriteria tersebut adalah (1) Mempublikasikan laporan tahunannya selama 5 (lima) tahun berturutturut mulai dari tahun 2010-2014, (2) Laporan Keuangan berakhir bulan desember, (3) Memiliki laba positif.

\section{Definisi Operasional Variabel}

\section{a. Variabel Dependen}

Variabel dependen dalam penelitian ini adalah tingkat pengungkapan tanggung jawab sosial secara syariah pada laporan tahunan perusahaan syariah yang diukur dengan nilai (score) dari indeks Islamic Social Reporting (ISR). Indeks ISR dalam penelitian ini adalah indeks yang diadopsi dari penelitian Raditya (2012), Widiawati dan Raharja, Othman and Thani (2010) yang merupakan hasil adaptasi dari indeks ISR yang dibuat oleh Haniffa dan Othman et.al dengan beberapamodifikasi sesuai penelitian. Selanjutnya pengukuran indeks ISR setelah skoring dilakukan dengan rumus sebagai berikut:

$$
\text { Disclosure level }=\frac{\text { Jumlah } \text { skor disclosure yang dipenuhi }}{\text { jumlah } \text { skor maksimum }}
$$




\section{b. Variabel Independen}

\section{a. Ukuran Perusahaan (Size)}

Ukuran perusahaan diproksikan dengan log natural total aset, tujuannya agar mengurangi perbedaan yang signifikan antara ukuran perusahaan besar dan ukuran perusahaan kecil sehingga data total aset dapat terdistribusi normal. Rumus yang digunakan untuk mengukur variabel size adalah :

Size $=\log$ natural (total aset)

\section{b. Profitabilitas}

Rasio profitabilitas yang digunakan dalam penelitian ini adalah Return on Asset (ROA). Return on Asset (ROA) adalah rasio antara laba bersih terhadap total aset. Rumus yang digunakan untuk mengukur variabel profitabilitas adalah :

$$
\text { Return on Asset }(\mathrm{ROA})=\frac{\text { laba bersih setelah pajak }}{\text { total aset }}
$$

\section{c. Proporsi dewan komisaris independen}

Proporsi dewan komisaris independen merupakan jumlah anggota dewan komisaris perusahaan. proporsi dewan komisaris diukur dengan menggunakan indikator jumlah anggota dewan komisaris perusahaan, baik yang berasal dari internal perusahaan maupun dari eksternal perusahaan.

\section{d. Leverage}

Leverage yaitu rasio yang digunakan untuk menilai kemampuan perusahaan dalam memenuhi kewajiban jangka panjang. Rumus yang digunakan untuk mengukur variabel Leverage adalah:

Debt to total asets ratio $=\frac{\text { Total Kewaji }}{\text { Total Aktin }}$

\section{Analisis Data}

\section{a. Analisis Statistik Deskriptif}

Analisis statistik deskriptif digunakan untuk menjelaskan deskripsi data dari seluruh variabel yang akan dimasukkan dalam model penelitian yang dilihat dari nilai minimum, nilai maksimum, rata- rata (mean) dan standar deviasi. 
326 \} Pengungkapan islamic Social Reporting pada Perbankan Syariah

\section{b. Uji Asumsi Klasik}

Uji asumsi klasik dilakukan untuk mengetahui apakah data layak untuk dianalisis.

\section{1) Uji Normalitas}

Uji normalitas bertujuan untuk menguji apakah dalam model regresi, variabel pengganggu atau residual berdistribusi normal. Penelitian ini menggunakan normal probability plot serta uji Kolmogorov-Smirnov (K-S).

\section{2) Uji Multikolinearitas}

Uji multikolinearitas bertujuan untuk menguji apakah model regresi ditemukan adanya korelasi antarvariabel bebas (independen). Jika hasil penelitian menunjukkan nilai Variance Inflation Factor (VIF) $\geq 10$ berarti ada multikolinearias, sebaliknya jika nilai VIF $<10$ berarti tidak ada multikolinearitas.

\section{3) Uji Autokorelasi}

Uji autokorelasi bertujuan menguji apakah dalam model regresi linear ada korelasi antara kesalahan pengganggu pada periode $\mathrm{t}$ dengan kesalahan pengganggu pada periode $\mathrm{t}-1$ (sebelumnya). Uji Durbin-Watson adalah salah satu alat uji untuk mengetahui apakah suatu model regresi terdapat autokorelasi. Nilai Durbin-Watson akan dibandingkan dengan nilai dalam tabel Durbin- Watson untuk mendapatkan batas bawah bawah (DL) dan batas atas (DU) dengan tingkat signifikansi $\alpha=5 \%$.

\section{4) Uji Heterokedastisitas}

Untuk mendeteksi ada tidaknya heteroskedastisitas adalah dengan melihat grafik plot antara nilai prediksi variabel dependen dengan residulnya. Artinya, deteksi adanya heteroskedastisitas dilakukan dengan melihat ada tidaknya pola tertentu pada grafik scatter plot, dimana sumbu $\mathrm{X}$ adalah $\mathrm{Y}$ yang telah diprediksi, dan sumbu X adalah residual (Y prediksi-Y sesungguhnya) yang telah di-studentized. Jika ada pola tertentu, seperti titik-titik yang ada membentuk pola tertentu yang teratur (bergelombang, melebar, kemudian menyempit), maka mengindikasikan telah terjadi heteroskedastisitas. Namun jika tidak ada pola yang jelas, serta titik-titik menyebar di atas dan di bawah angka 0 pada sumbu Y, maka tidak terjadi heteroskedastisitas. 


\section{c. Analisis Regresi Berganda}

Metodeanalisis yang digunakan pada penelitian ini adalah regresilinear berganda yang mengukur inten sitas dua variabel, yaitu variabelin dependen dan variabel dependen, serta membuat dugaan nilai variabel dependen $(\mathrm{Y})$ atas dasar nilai variabel independen $(\mathrm{X})$, dengan rumus:

$$
Y=a+b_{1} x_{1}+b_{2} x_{2}+b_{3} x_{3}+\cdots \ldots+b_{n} x_{n}
$$

Berdasarkan variabel-variabel yang digunakan dalam penelitian ini, maka model regresi linear berganda pada penelitian ini diformulasikan sebagai berikut:

$$
\mathrm{ISRD}=\alpha+\mathrm{b} 1 \text { size }+\mathrm{b} 2 \text { profit }+\mathrm{b} 3 \text { prop }+\mathrm{b} 4 \text { Lev }++\mathrm{e}
$$

Keterangan :

$$
\begin{aligned}
& \text { ISRD = Islamic Social Reporting Disclosure } \\
& \text { size } \quad=\text { Ln (total aset) } \\
& \text { profit } \quad=\text { Profitabilitas }(\mathrm{ROA}) \\
& \text { Prop } \quad=\text { Proporsi dewan komisaris Independen } \\
& \text { Lev } \quad=\text { Leverage } \\
& \alpha \quad=\text { Intercept } \\
& \mathrm{b} 1, \ldots, \mathrm{b} 4=\text { Koefisien regresi } \\
& \text { e }=\text { Error }
\end{aligned}
$$

\section{d. Koefisien Determinasi}

Untuk mengetahui tingkat ketepatan suatu garis regresi dapat diketahui dari besar kecilnya koefisisen determinasi yaitu dilihat dari nilai Adjusted $R$ Square. Besarnya harga koefisien determinasi dapat dilihat pada table output Model Summary hasil pengolahan data menggunakan SPSS 17.

Semakin nilai Adjusted $R$ Square mendekati 1 maka semakin cocok garis regresi untuk meramalkan variabel tak bebas. Adjusted $R$ Square yang disebut koefisien determinasi berganda mempunyai dua kegunaan:

1) Sebagai ukuran ketepatan suatu garis regresi yang diterapkan terhadap suatu kelompok data hasil observasi. Makin besar Adjusted $R$ Squaremakin tepat suatu garis regresi, demikian sebaliknya.

2) Untuk mengukur besarnya sumbangan variabel bebas $X$ terhadap variasi (naik turunnya) Y. 
328 \} Pengungkapan islamic Social Reporting pada Perbankan Syariah

\section{e. Uji Signifikasi Parameter Individual (Uji Statistik t)}

Uji statistik $\mathrm{t}$ pada dasarnya menunjukkan seberapa jauh pengaruh satu variabel penjelas secara individu dalam menerangkan variasi variabel terikat. Uji $\mathrm{t}$ digunakan untuk menguji suatu hipotesis mengenai sikap koefisiensi regresi parsial individual terhadap variabel dependennya. Uji $t$ dilakukan dengan membandingkan Sig t dengan tingkat signifikasi sebesar 5\%. Apabila Sig $\mathrm{t}<0,05$ maka Ho ditolak. Hal ini menunjukkan adanya hubungan yang signifikan antara variabel independen dengan variabel dependennya. Sebaliknya, bila nilai Sig t $>0,05$ maka Ho diterima. Hal ini menunjukkan tidak adanya hubungan yang signifikan antara variabel independen dengan variabel dependennya (Ghozali, 2006).

\section{HASIL DAN PEMBAHASAN}

Dari total sampel yang berhasil kami kumpulkan yaitu sebanyak 15 Perusahaan dengan berdasarkan pada laporan Tahunan perusahaan selama kurun waktu 2010-2014, yang memenuhi persyaratan untuk digunakan sebagai sampel penelitian adalah 6 (enam) perusahaan perbankan syariah yang memenuhi kriteria sampel, yaitu:

1. Bank BNI syariah

2. Bank BRI syariah

3. Bank Bukopin Syariah

4. Bank Mandiri syariah

5. Bank Mega syariah

\section{Uji Asumsi Klasik}

Sebelum melakukan analisis regresi berganda, maka perlu dilakukan pengujian terhadap asumsi data, yaitu 4 asumsi klasik berikut:

a. Uji Normalitas

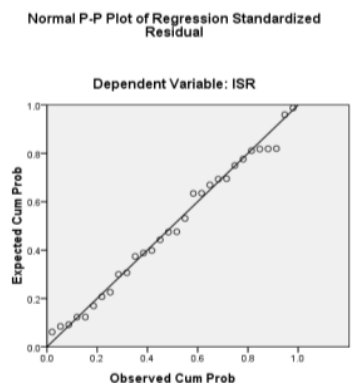

..::: Malia: Jurnal Ekonomi Islam, Volume 10 Nomor 2 Juni 2019 :::... 
Pada hasil output SPSS 17 yang ditunjukkan pada gambar di atas, tampak dari gambar tersebut menunjukkan bahwa data bergerombol disekitar garis uji yang mengarah ke kanan atas, tidak ada gerombolan plot data yang terletak jauh dari garis uji normalitas. Dengan demikian data tersebut bisa dikatakan mempunyai sebaran yang normal atau dengan kata lain telah memenuhi asumsi normalitas sebaran data.

b. Uji Multikolinearitas

Uji multikolinearitas bertujuan untuk menguji apakah model regresi ditemukan adanya korelasi antarvariabel bebas (independen). Jika hasil penelitian menunjukkan nilai Variance Inflation Factor (VIF) $\geq 10$ berarti ada multikolinearias, sebaliknya jika nilai VIF < 10 berarti tidak ada multikolinearitas. Adapun hasil Uji Multikolinieritas Adalah sebagai berikut:

\begin{tabular}{|c|c|}
\hline \multicolumn{2}{|c|}{ Collinearity Statistics } \\
\hline Tolerance & VIF \\
\hline .457 & 2.190 \\
.881 & 1.135 \\
.925 & 1.081 \\
.412 & 2.424 \\
\hline
\end{tabular}

Dependent Variabel: CSR

Dari tabel tersebut di atas dapat disimpulkan bahwa untuk ke4 variabel bebas tidak terjadi multikolineritas dengan ditunjukkan nilai VIF dari ke-4 variabel bebas yang lebih kecil dari 10.

c. Uji Autokorelasi

Pendeteksian terhadap adanya Autokorelasi (terjadinya hubungan antara variabel-variabel bebas itu sendiri atau berkorelasi sendiri), dengan hipotesis:

Ho : $\mathrm{p}=0$, tidak terjadi autokorelasi antar galat (error)

$\mathrm{H} 1: \mathrm{p}>0$, terjadi autokorelasi antar galat (error)

Statistik Uji yang digunakan adalah Durbin Watson.

$\mathrm{DW}<-2 \quad=$ ada autokorelasi positif

$-2<\mathrm{DW}<+2=$ Tidak ada autokorelasi

$\mathrm{DW}>+2 \quad=$ ada autokorelasi negatif 
330 \} Pengungkapan islamic Social Reporting pada Perbankan Syariah

Model Summary ${ }^{b}$

\begin{tabular}{|c|c|}
\hline Model & Durbin-Watson \\
\hline 1 & 1.712 \\
\hline
\end{tabular}

a. Predictors: (Constant), PROP, LEV, ROA, SIZE

b. Dependent Variable: ISR

Berdasarkan Tabel di atas diperoleh nilai dw berada diantara +2 dan -2 atau yaitu $-2<1.712<+2$. Berarti dapat disimpulkan bahwa galat nilai-nilai pengamatan bersifat bebas (tidak ada autokorelasi).

\section{Uji Heterokedastisitas}

Untuk mendeteksi ada tidaknya heteroskedastisitas adalah dengan melihat grafik plot antara nilai prediksi variabel dependen dengan residulnya. Artinya, deteksi adanya heteroskedastisitas dilakukan dengan melihat ada tidaknya pola tertentu pada grafik scatter plot, dimana sumbu $\mathrm{X}$ adalah $\mathrm{Y}$ yang telah diprediksi, dan sumbu $\mathrm{X}$ adalah residual ( $\mathrm{Y}$ prediksi-Y sesungguhnya) yang telah di-studentized. Jika ada pola tertentu, seperti titik-titik yang ada membentuk pola tertentu yang teratur (bergelombang, melebar, kemudian menyempit), maka mengindikasikan telah terjadi heteroskedastisitas. Namun jika tidak ada pola yang jelas, serta titik-titik menyebar di atas dan di bawah angka 0 pada sumbu $\mathrm{Y}$, maka tidak terjadi heteroskedastisitas (Santoso, 2003).

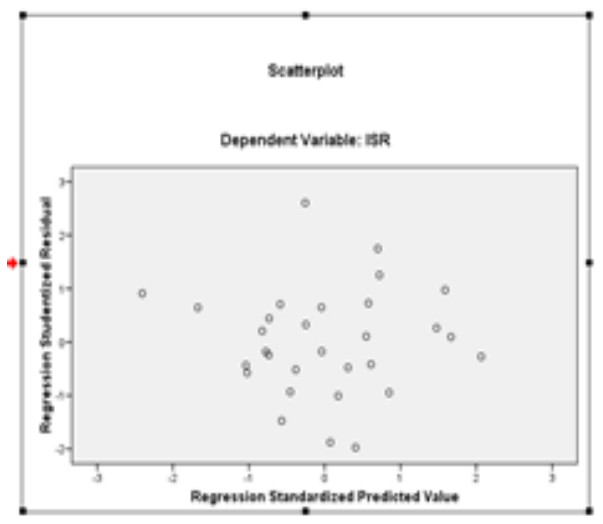

\section{Analisis Data}

\section{a. Koefisien Determinasi:}

Hasil penelitian ini menunjukkan bahwa nilai Adjusted $\mathrm{R}$ square sebesar 0.518 atau $51,8 \%$. Hal ini menunjukkan adanya pengaruh yang kuat antara variabel $\mathrm{x}$ terhadap variabel $\mathrm{y}$. 
Model Summary

\begin{tabular}{|c|c|c|c|c|c|}
\hline Model & $\mathrm{R}$ & R Square & $\begin{array}{c}\text { Adjusted R } \\
\text { Square }\end{array}$ & $\begin{array}{c}\text { Std. Error } \\
\text { of the } \\
\text { Estimate }\end{array}$ & $\begin{array}{c}\text { Durbin- } \\
\text { Watson }\end{array}$ \\
\hline 1 & $.764 \mathrm{a}$ & .584 & .518 & .06543 & 1.712 \\
\hline
\end{tabular}

a. Predictors: (Constant), PROP, LEV, ROA, SIZE

b. Dependent Variable: ISR

\section{b. Pengujian Regresi Berganda}

Berdasarkan hasil pengujian, maka hasil regresi dapat disusun dalam bentuk tabel sebagai berikut:

\section{Coefficients $^{\mathrm{a}}$}

\begin{tabular}{|c|c|c|c|c|c|c|c|c|}
\hline & \multirow[b]{2}{*}{ Model } & \multicolumn{2}{|c|}{$\begin{array}{l}\text { Unstandardize } \\
\text { d Coefficients }\end{array}$} & \multirow{2}{*}{\begin{tabular}{|c|}
$\begin{array}{c}\text { Standardized } \\
\text { Coefficients }\end{array}$ \\
Beta
\end{tabular}} & \multirow[b]{2}{*}{$\mathrm{t}$} & \multirow[b]{2}{*}{ Sig. } & \multicolumn{2}{|c|}{ Collinearity Statistics } \\
\hline & & $\mathrm{B}$ & $\begin{array}{l}\text { Std. } \\
\text { Error }\end{array}$ & & & & Tolerance & VIF \\
\hline \multirow[t]{5}{*}{1} & (Constant) & 1.143 & .151 & & 7.591 & .000 & & \\
\hline & LnSize & -.026 & .006 & -.849 & -4.536 & .000 & .457 & 2.190 \\
\hline & ROA & .015 & .025 & .077 & .573 & .572 & .881 & 1.135 \\
\hline & Lev & -.002 & .001 & -.306 & -2.331 & .028 & .925 & 1.081 \\
\hline & Prop & -.038 & .027 & -.283 & -1.439 & .163 & .412 & 2.424 \\
\hline
\end{tabular}

a. Dependent Variable: ISR

Berdasarkan tabel di atas, maka persamaan regresi dapat dirumuskan sebagai berikut :

$$
\mathrm{Y}=1.143-0.026 \mathrm{X}_{1}+0,015 \mathrm{X}_{2}-0.002 \mathrm{X}_{3}-0.038 \mathrm{X}_{4} \text {. }
$$

c. Uji T

Sedangkan hasil uji t menunjukkan bahwa variabel Size (ukuran perusahaan dan variabel Leverage memiliki pengaruh terhadap pengungkapan ISR (Islamic social reporting).

\section{Coefficients $^{\mathrm{a}}$}

\begin{tabular}{|cc|c|c|}
\hline \multicolumn{2}{|c|}{ Model } & $\mathrm{t}$ & Sig. \\
\hline 1 & (Constant) & 7.591 & .000 \\
& LnSize & -4.536 & .000 \\
\hline
\end{tabular}


332 \} Pengungkapan islamic Social Reporting pada Perbankan Syariah

\begin{tabular}{c|c|c|} 
ROA & .573 & .572 \\
Lev & -2.331 & .028 \\
Prop & -1.439 & .163 \\
\hline
\end{tabular}

a. Dependent Variable: ISR

\section{PENGARUH UKURAN PERUSAHAAN TERHADAP ISR}

Berdasarkan hasil pengujian statistik di tabel 4.14 diatas, nilai $\mathrm{t}$ statistik sebesar $-4,536$. Karena $t$ statistik $>t$ table maka dapat dinyatakan bahwa hipotesis 1 dapat diterima. Hal ini juga dapat dilihat nilai signifikansi $<0,05$. Hal ini berarti bahwa Size berpengaruh negatif signifikan terhadap pengungkapan islamic social reporting, yang berarti semakin besar ukuran perusahaan, maka pengungkapan sosial dan lingkungan yang dilakukan oleh perusahaan akan semakin meningkat. Hasil penelitian ini selaras dengan penelitian Othman et al., ukuran perusahaan secara positif signifikan mempengaruhi tingkat pengungkapan ISR. Perusahaan yang lebih besar adalah perusahaan yang memiliki sumber daya lebih banyak daripada perusahaan yang lebih kecil. Dengan demikian, perusahaan yang lebih besar sudah pasti memiliki pembiayaan, fasilitas, dan sumber daya manusia yang lebih banyak untuk dapat melakukan pengungkapan yang lebih sesuai dengan prinsip Islam.

\section{PENGARUH PROFITABILITAS TERHADAP ISR}

Hasil pengujian statistic menunjukkan nilai t hitung sebesar 0.573 dan karena signifikan diatas 5\%, artinya tidak ada pengaruh antara variabel ROA dengan pengungkapan islamic social reporting. Hasil penelitian ini selaras dengan penelitian yang dilakukan oleh Ho dan Wong, Hossain et al, Anggraini, Reverte, dan Aulia \& Kartawijaya menyatakan bahwa profitabilitas tidak berpengaruh terhadap pengungkapan laporan tahunan perusahaan. Haniffa, menyatakan bahwa dalam pandangan islam perusahaan yang memiliki niat untuk melakukan pengungkapan penuh tidak akan mempertimbangkan apakah perusahaan tersebut untung atau rugi.

Hasil ini tidak sejalan dengan Othman et al yang membuktikan bahwa ROA berpengaruh positif terhadap pengungkapan tanggung jawab sosial yang sesuai dengan prinsip Islam. Teori keagenan memaparkan bahwa manajer perusahaan dengan profit yang lebih tinggi kemungkinan akan melakukan pengungkapan yang lebih luas dengan tujuan untuk memperoleh

..::: Malia: Jurnal Ekonomi Islam, Volume 10 Nomor 2 Juni 2019 :::... 
keuntungan pribadi, seperti promosi jabatan dan kompensasi. Sebaliknya, apabila profit perusahaan menurun, manajer akan cenderung mengurangi informasi yang diungkapkan dengan tujuan untuk menyembunyikan alasanalasan mengapa profit perusahaan mengalami penurunan.

\section{PENGARUH LEVERAGE TERHADAP ISR}

Berdasarkan hasil pengujian statistik nilai t statistik sebesar -2.331 . Karena $\mathrm{t}$ hitung $>\mathrm{t}$ table dan nilai probabilitas lebih kecil dari 0.05 yaitu 0.028 maka dapat dinyatakan bahwa terdapat hubungan negatif signifikan antara leverage (DER) dengan pengungkapan islamic social reporting. Hasil penelitian ini selaras dengan penelitian Belkaoui dan Karpik yang menjelaskan bahwa Leverage berpengaruh negative terhadap pengungkapan tanggung jawab sosial perusahaan. Menurutnya keputusan untuk mengungkapkan informasi sosial akan mengikuti suatu pengeluaran untuk pengungkapan yang menurunkan pendapatan. Hal ini sesuai dengan teori keagenan dimana manajemen dengan tingkat leverage yang tinggi akan mengurangi pengungkapan sosialnya demi menghindari pemeriksaan dari kreditur. Hasil penelitian ini bertolak belakang dengan Masruki, et.al yang membuktikan bahwa tingkat leverage tidak berpengaruh terhadap pengungkapan sosial yang dilakukan oleh bank syariah di Malaysia. Hal ini dikarenakan leverage yang diukur dengan rasio kewajiban terhadap ekuitas pada bank syariah akan berbeda dengan entitas lainnya. Kewajiban pada bank syariah merupakan sumber utama penghasilan laba dengan sistem bagi hasil nisbah keuntungan. Sedangkan pada entitas non bank, kewajiban merupakan suntikan modal untuk memaksimalkan laba.

\section{PENGARUH KOMPOSISI DEWAN KOMISARIS INDEPENDEN TERHADAP ISR}

Hasil uji parsial menunjukan variabel independen yakni Komposisi Dewan Komisaris Independen mempunyai nilai sig $0.163>0.05$ dan arah koefisien regresi -1.439 yang berarti variabel komposisi dewan komisaris independen berpengaruh negatif dan tidak signifikan terhadap pengungkapan ISR. Dengan demikian hipotesis keempat (H4) yang menyatakan bahwa komposisi dewan komisaris independen berpengaruh positif dan signifikan terhadap pengungkapan ISR pada Perbankan Syariah di Indonesia dinyatakan ditolak. Hal ini tidak sejalan dengan penelitian Nurkhin yang menyatakan 
$334\}$ Y Pengungkapan islamic Social Reporting pada Perbankan Syariah

bahwa komposisi dewan komisaris independen berpengaruh terhadap pengungkapan tanggung jawab sosial perusahaan.

\section{KESIMPULAN}

Penelitian ini bertujuan untuk mengetahui bagaimana pengungkpan Islamic Social Reporting (ISR) pada perbankan syaiah serta faktor-faktor apa saja yang mempengaruhinya. Pengungkapan tanggung jawab sosial oleh perbankan syariah sudah seharusnya mengacu pada standar pengungkapan yang berdasarkan prinsip Islam. Standar yang digunakan dalam penelitian ini adalah indeks Islamic Social Reporting yang merupakan kerangka pelaporan berdasarkan prinsip Islam yang diusulkan oleh Haniffa dan dikembangkan oleh Haniffa dan Hudaib dan Othman et al. Hasil penelitian menunjukkan bahwa variabel Ukuran Perusahaan dan Leverage berpengaruh Signifikan terhadap ISR sedangkan Profitabilitas dan Komposisi dewan komisaris tidak berpengaruh signifikan terhadap ISR.

\section{DAFTAR PUSTAKA}

Dusuki, A.W.,\& Dar, H. (2005). Stakeholders' perceptions of Corporate Social Responsibility of Islamic Banks: Evidence From Malaysian Economy. International Conference on Islamic Economics and Finance.

Eddy Rismanda Sembiring. (2003). Karakteristik Perusahaan dan Pengungkapan Tanggung Jawab Sosial. Tesis. Universitas Diponegoro

Freedman, M. \& Jaggi. M. (1988). An Analysis of the Association between Pollution Disclosure and Economic Performance. Accounting, Auditing and Accountability Journal, Vol.1 No.2 : 43-5 8

Fitria, Soraya dan Dwi Hartanti. 2010. Studi Perbandingan Pengungkapan Berdasarkan Global Reporting Initiative Indeks Dan Islamic Sosial Reporting Indeks. Simposium Nasional Akuntansi. Purwokerto. Proceeding

Fauziah, Khusnul dan J, Prabowo Yudho. 2013. Analisis Pengungkapan Tanggungjawab Sosial Perbankan Syariah di Indonesia Berdasarkan Islamic Social Reporting Indeks. Jurnal Dinamika Akuntansi Vol. 5, No. 1, Maret 2013. 
Hartanti, Dwi (2006) "Makna Corporate Social Responsibility: Sejarah dan Perkembangannya". Economics Business \& Accounting Review. Edisi III/ September-Desember.

Hasibuan, Chrysanti dan Sedyono (2002) "Etika bisnis, Corporate Social Responsibility (CSR) dan PPM". PPM Institute of Managemant, 27 November.

Hendriksen, Eldon S dan Widjajant, Nugroh "Teori Akuntansi". Edisi ke-4 jilid 2. Jakarta: Erlangga.

Haniffa, R. (2002). Social Reporting Disclosure-An Islamic Perspective. Indonesian Management \& Accounting Research 1 (2), pp.128-146.

Haniffa, R \& Hudaib, M. (2004). Disclosure Practices of Islamic Financial Institutions: AnExplatory Study. Working Paper Series No 04/32.

Hapsoro, Dody .2008. Pengaruh Mekanisme Corporate Governance Terhadap Kinerja Perusahaan, Study Empiris di Pasar Modal Indonesia. Jurnal Akuntansi dan Manajemen vol 19 No 3,pp 155-157

HafiezSofyaniet. al., "Islamic Social Reporting Index Sebagai Model PengukuranKinerjaSosialPerbankanSyariah (StudiKomparasi Indonesia dan Malaysia)", JurnalDinamikaAkuntansi, Vol. 4 No. 1,2012, h. 46.

Indriantoro, Nur dan Bambang, Supomo (1999) "Metodologi Penelitian Bisnis: Untuk Akuntansi dan Manajemen". Edisi 1. Yogyakarta: BPFE.

Imam Ghozali. (2011). Aplikasi Analisis Multivariate Dengan Program SPSS. Semarang: BP Universitas Diponegoro

Ikatan Akuntansi Indonesia (IAI) (1999) "Standar Akuntansi Keuangan". Buku Satu. Jakarta: Salemba Empat.

Nizar, M. Pengaruh Ekuivalen Nisbah Bagi Hasil Tabungan, Deposito, Dan Frekuensi Pencairan Pembiayaan Murabahah Terhadap Jumlah Nasabah Baru di BMT al-Yasini Wonorejo Pasuruan.

Othman, R., Md. Thani, A., K. Ghani, E. (2009). Determinants of Islamic Social Reporting Among Top Shariah-Approved Companies in Bursa Malaysia. Research Journal of International Studies - Issue 12(October, 2009).

Rasyid, Abdul Idris. Corporate Social Responsibility (CSR) Sebuah Gagasan dan Implementasi. Fajar Online. 22 November 2005.

Retno, Reni anggraini Fr (2006) "Pengungkapan Informasi Sosial dan Faktorfaktor yang Mempengaruhi Pengungkapan Informasi Sosial dalam 
336 \} Pengungkapan islamic Social Reporting pada Perbankan Syariah

Laporan Keuangan Tahunan". Simposium Nasional Akuntansi IX. Padang, 23-26 Agustus.

Rizkiningsih, Priyesta. 2012. "Faktor-Factor yang Mempengaruhi Pengungkapan Islamic Social Reporting (ISR) : Studi Empiris pada Bank Syariah di Indonesia, Malaysia dan Negara -Negara Gulf Cooperation Coincil". Skripsi. Universitas Indonesia.

Sigit, Soehardi 1 (1999) "Pengantar Metodologi Penelitian Sosial-BisnisManajemen. FE Universitas Sarjanawijaya Tamansiswa.

Utomo, Muhammada Muslim (2000) "Prektek Pengungkapan Sosial pada Laporan Tahunan Perusahaan di Indonesia (Studi Perbandingan antara Perusahaan-perusahaan High Profile dan Low Profile)". Makalah disajikan pada SNA III.

Widiawati, Septi dan Raharja, Surya. 2012. Analisis Faktor - faktor yang Mempengaruhi Islamic Social Reporting Indeks Perusahaan Perusahaan yang terdapat pada Daftar Efek Syariah Tahun 2009 2011. Diponegoro Journal of Accounting, Volume 1, Nomor 2.

Yuniarti, Emylia (2003) "Pengungkapan Informasi Pertanggung jawaban Sosial Pada Perusahaan yang Terdaftar di BEJ". Jurnal Telaah dan Riset Akuntansi. Vol 1, No.2: 240-252. 